\title{
SELL ŽAIDYNIŲ DALYVIŲ NUOMONĖ APIE SPORTO PSICHOLOGIJĄ IR SPORTO PSICHOLOGO DARBĄ
}

\author{
Juozas Kasiulis \\ Lietuvos kūno kultūros akademija, Kaunas, Lietuva
}

\begin{abstract}
Juozas Kasiulis. Docentas socialinių mokslų (socialinès psichologijos) daktaras. Lietuvos kūno kultūros akademijos Sporto pedagogikos ir psichologijos katedros docentas. Mokslinių tyrimų kryptis — asmenybès psichologinės problemos.
\end{abstract}

\section{SANTRAUKA}

Sporto specialistai teigia, kad sèkmę varžybose lemia psichologinis sportininku parengtumas, o kq apie tai galvoja patys sportininkai? Tyrimo tikslas - išanalizuoti sportininku studentu nuomonę apie sporto psichologija ir sporto psichologo darbq. Siekiant šio tikslo sprendžiami tokie uždaviniai: ištirti sportininku studentu nuomonę apie sporto psichologija ir sporto psichologo darba; nustatyti respondentu lyties, sporto šakos, gyvenimo aplinkos bei pasirinktos profesijos sasajas su požiüriu i sporto psichologija ir sporto psichologo darbq. Tyrimo objektas — sporto psichologija ir sporto psichologo darbas studentu sportininku akimis.

Tyrimo metu panaudota specialiosios literatūros analizè, S. B. Martin ir kt. Požiūrio ì sporto psichologija (patikslinta forma) metodika (SPA-R) bei matematines statistikos metodai.

SPA-R sudaro dvi dalys: 1-a skirta informacijai apie respondenta; 2-a - nustatyti tolerancija sporto psichologijos atžvilgiu, pasitikejjima sporto psichologu, asmens atviruma ir kultūrinius ypatumus.

Duomenis apdorojant statistiškai naudota Microsoft Office Excel 2003 programa ir programinio paketo SPSS 13.0 versija. Duomenu analizé atlikta taikant Pirsono koreliacijos koeficienta, o požiūrio ì sporto psichologija (SPA-R) metodikos skaliu patikimumas tikrinamas naudojant Cronbach- $\alpha$ kriteriju.

2006 m. Estijoje vykstant SELL (Suomijos, Estijos, Latvijos ir Lietuvos) studentu sporto žaidynèms, SPA-R metodika apklausti 126 studentai sportininkai (83 vyrai ir 43 moterys): 40 iš Lietuvos, 38 iš Latvijos ir po 24 iš Estijos bei Suomijos, ¿vairiu sporto šaku ir aukštuju mokyklu. anglu, rusu ar lietuviu kalba pasirinktinai.

Tiriant paaiškejjo, kad 56,3\% studentu sportininku yra tolerantiški sporto psichologijos atžvilgiu, likusieji 43,7\% apklaustuju— mažiau arba visai netolerantiški. Procentine išraiška moterys kiek tolerantiškesnès (60,5\%) už vyrus (54,2\%), tačiau šis skirtumas statistiškai nepatikimas $(p=0,506)$. Respondentu gyvenamoji aplinka suponuoja kultūrinius skirtumus. Tyrimas parodè, kad tolerantiškiausi sporto psichologijai yra Suomijos apklaustieji (66,7\%), mažiausiai tolerantiški Latvijos (42,1\%). 57,9\% Latvijos, 40\% Lietuvos, 37,5\% Estijos ir 33,3\% Suomijos apklaustuju mano, jog lankymasis pas sporto psichologa kenkia ju reputacijai ir jie nenorètu, kad kas nors apie tai sužinotu.

Tyrimas parodè statistiškai reikšmingas $(p=0,029)$ respondentu lyties ir pasitikẻjimo psichologu sqsajas: sporto psichologu labiau pasitiki moterys (67,4\%) nei vyrai (47,0\%). Labiausiai sporto psichologu pasitiki Estijos respondentai (75,0\%), mažiausiai - Suomijos (tik 33,3\%) (p=0,010). Lietuvaičiu pasitikejiimas psichologu siekia 55,0\%.

Tyrimo metu paaiškejjo, kad respondentų asmeninis atvirumas glaudžiausiai susijęs su ju išsilavinimu: atviriausi — studijuojantys ar jau turintys bakalauro $(63,8 \%)$ ir magistro (60\%) laipsni, uždariausi - asmenys su viduriniu išsilavinimu (63,9\%) ir baigę koledža (57,1\%) $(p=0,012)$.

Pastebèta statistinè ( $p=0,053)$ sasaju tarp būsimos respondentu profesijos ir asmeninio atvirumo tendencija: atviriausi - būsimi medikai (77,8\%) ir komunikaciju specialistai $(57,1 \%)$, uždariausi — švietimo (83,3\%), architektūros $(57,1 \%)$, inžinerijos $(54,5 \%)$ ir humanitarinius mokslus (54,5\%) studijuojantys sportininkai.

Tyrimo rezultatai leidžia pateikti tokias išvadas: Baltijos šaliu (SELL) studentai sportininkai yra tolerantiški sporto psichologijai ir sporto psichologo darbo klausimais. Tik praktiškai jie netiki konsultacijos paveikumu, nes $90 \%$ apklaustuju nè karto nëra apsilankę pas sporto psichologa, o norètu apsilankyti tik $15,9 \%$ respondentu.

Tolerancijos sporto psichologijai požiūriu statistiškai reikšmingo skirtumo tarp tiriamu moteru ir vyru nustatyti nepavyko $(p=0,506)$, nors moterys tolerantiškesnès (60,5\%) už vyrus (54,2\%). Individualiuju šaku sportininkai tolerantiškesni sporto psichologijai už sportiniu žaidimu šaku apklaustuosius.

Tyrimas parodè, kad būsimoji specialybè ir noras apsilankyti pas psichologa yra glaudžiai susiję $(p=0,019)$. Labiausiai to nori būsimi medikai, švietimo darbuotojai, teisininkai, verslininkai ir administratoriai, mažiausiai - būsimi architektai, inžinieriai ir humanitarai. Tai, kad iš 126 apklaustuju tik 13 asmenu yra lankęsi pas sporto psichologa, kelia įvairiausiu klausimu.

Raktažodžiai: sporto psichologija, sporto psichologo darbas, tolerancija sporto psichologijai, pasitikejimas, atvirumas, kultūrinès ypatybès.

\section{IVADAS}

$\mathrm{N}$ ūdiena pasižymi audringu žmonių aktyvumu įvairiausiose veiklos srityse, tarp ju ir sporte. Tačiau ir šiandien viena iš

silpniausių sportinès veiklos grandžių yra psichologiniai jos komponentai, nes sporto psichologija yra palyginti naujas, jaunas mokslas. Teorine jos 
dalis kiek stipresnè, aiškesnè, bet psichologinio sportininkų rengimo metodikos problemos tikrai neišspręstos: blaškomasi tarp dviejų kraštutinumu — vieni teigia, kad psichologinis sportininku rengimas - tik trenerio reikalas, kiti mano, kad ¿vairiausių rengimo priemoniu sistemą parenka ir igyvendina tik psichologas. Psichologinio sportininkų rengimo rezultatai priklauso nuo trenerio žinių (sutinkami visiško jų neturejjimo atvejai) arba nuo psichologo subjektyvumo / objektyvumo parenkant metodiką.

Savaime iškyla sistemos valdymo klausimas. Užsakovais turètų būti sporto vadovai, sporto klubai, komandos. Jie kelia treneriams ir psichologams psichologinio sportininkų rengimo uždavinius, formuluoja socialinį užsakymą, kontroliuoja jo realizavima, nes jie vadovauja šiam procesui, valdo finansinius išteklius.

Tas triumviratas (užsakovas-treneris-psichologas) privalètų atsižvelgti į tai, kad ilgai lankydamas sporto mokyklą, dalyvaudamas sporto stovyklose, varžybose, besimokydamas Olimpinio rezervo centre, Futbolo akademijoje jaunasis sportininkas iš dalies patiria sensorinę ir socialinę izoliacija, psichologini badą, taip vadinamą deprivaciją. Sąlygiškai uždaroje sistemoje jauni sportininkai per vienerius - pusantrų metų išgyvena kritinius vystymosi laikotarpius (paūmèjimas - 7-ą ir 12-ą mènesi): nublanksta doméjimasis sporto šaka, sumažěja adaptacija, padidèja jautrumas ir jaudrumas, kyla psichine itampa, stabteli pažanga ir pan. (Сопов, 2007). Todèl jie patys meta sportą arba yra išbraukiami iš sąrašų. Šioje srityje daug kas priklauso nuo sporto psichologo pozicijos ir veiklos, o pastaroji - nuo jo statuso, jo kompetencijos ir žmogiškujų savybių. Deja, ir jų veiklai turi įtakos besiplečianti rinkos psichologija. Sporto psichologas iš esmès dirba su sportininkais ir treneriais. Todèl keltas tyrimo tikslas toks - išsiaiškinti, ką apie sporto psichologiją ir sporto psichologo darbą mano studentai sportininkai. Tyrimui pasirinkti SELL (Suomijos, Estijos, Latvijos ir Lietuvos) žaidynių dalyviai sportininkai studentai.

Tyrimo uždaviniai: 1) ištirti sportininkų studentų požiūrị i sporto psichologiją ir sporto psichologo darbą; 2) nustatyti respondentų lyties, sporto šakos, pasirinktos profesijos, gyvenimo aplinkos sąsajas su sporto psichologija ir sporto psichologo darbu.

Tyrimo objektas - sporto psichologija ir sporto psichologo darbas sportininkų studentu požiūriu.

\section{TYRIMO METODIKA}

Tyrimo metu taikyta specialiosios literatūros analizé, požiūrio i̇ sporto psichologiją nustatymo metodika ir matematinès statistikos metodai.

Naudota požiūrio ì sporto psichologiją (patikslinta forma) metodika (Sport Psychology Attitudes - Revised Form (SPA-R)). Originalią Požiūrio i sporto psichologiją (The Attitudes Toward Seeking Sport Psychology Consultation Questionnaire) metodiką parengè S. B. Martin, C. A. Wrisberg, P. A. Beitel ir J. W. Lounsbury 1997 metais. Vèliau ji buvo modifikuota i Sporto psichologijos nuostatas - patikslinta (SPA-R) (Martin et al., 2002).

Metodiką sudaro dvi dalys: 1-a (11 klausimu) skirta informacijai apie respondentą ir jo kontaktus su sporto psichologu, 2-a (25 klausimai) - nustatyti keturis dalykus: a) toleranciją (7 klausimai), b) pasitikèjimą (8 klausimai), c) asmens atviruma (6 klausimai) ir d) kultūrinius ypatumus (4 klausimai).

Tolerancijos skalè atskleidžia respondento tolerantiškumą sporto psichologijos atžvilgiu, t. y. ar apsilankymas pas sporto psichologą turi ittakos sportininko reputacijai. Pasitikejjimo skalè atskleidžia respondento pasitikejjimą sporto psichologu, t. y. ar asmuo tiki, kad sporto psichologas gali padèti jam pasiekti geresnių rezultatų, išspręsti kilusias problemas. Asmens atvirumo skalè rodo, kiek žmogus atviras kitiems: kuo jis atviresnis, tuo labiau linkęs naudotis kitų specialistu pagalba sprendžiant įvairias problemas, ir atvirkščiai. Kultūrinių skirtumų skalè rodo, ar žmogui turi įtakos kultūriniai, etniniai, aplinkos ypatumai, t. y. parodo asmens požiūrị i kitos etninès kilmès, kultūros žmones, konkrečios kultūros atstovų elgesio standartus.

Kiekvieną šios dalies teigini respondentas vertino pažymedamas sutikimo su juo lygi nuo 1 (visai nesutinku) iki 7 (tikrai sutinku) balų.

Atsižvelgiant i SPA-R metodikoje pateiktą sutikimo su teiginiais lygio ịvertinimo lentelę, kiekviena skalè buvo padalyta $\mathfrak{i}$ dvi grupes, išvedus jos vidurki $(\overline{\mathrm{x}})$ : tolerancijos skale $-\overline{\mathrm{x}}=23$ : remiantis tuo, 1-a grupè - nuo 1 iki 23 balų imtinai ir 2-a grupè - nuo 24 iki 49 balų; pasitikejjimo skale $-\overline{\mathrm{x}}=36$ : tad 1 gr. - nuo 1 iki 36 balu, 2 gr. - nuo 37 iki 56 balu imtinai; asmeninio atvirumo skale $-\overline{\mathrm{x}}=28$ : tai 1 gr. - nuo 1 iki 28, 2 gr. - nuo 29 iki 42 balų imtinai; kultūrinių ypatumu skale $-\overline{\mathrm{x}}=17$ : tai 1 gr. - nuo 1 iki 17 , 2 gr. - nuo 18 iki 28 balų imtinai. 
Tolerancijos skalèje respondentas, surinkęs $1-23$ balus, yra tolerantiškas sporto psichologijai, o surinkęs 24-49 balus - netolerantiškas jai.

Pasitikèjimo skalèje respondentas, surinkęs 1-36 balus, nepasitiki sporto psichologu, o surinkęs 37-56 balus pasitiki juo.

Asmeninio atvirumo skaleje surinkti $1-28$ balai rodo, kad respondentas yra atviras kitiems asmenims, linkęs priimti specialistu pagalbą, o 29-42 balai - uždarumą, vengimą naudotis kitu pagalba, bandymą problemas spręsti pačiam.

Respondentui, kultūrinių ypatumų skalèje surinkusiam $1-17$ balu, neturi itakos ar menkai ji veikia kultūriniai, etiniai ypatumai (juos lemia gyvenamoji vieta), o surinkus 18 -28 balus - veikia stipriai.

Duomenis apdorojant statistiškai, panaudota Microsoft Office Excel 2003 programa ir programinio paketo SPSS 13.0 versija. Duomenu analizė atlikta taikant Pirsono koreliacijos koeficientą, t. y. jei $\mathrm{p}<0,05$, tada skirtumas laikomas statistiškai reikšmingas, o kai p reikšmè yra nuo 0,05 iki 0,100 , laikoma statistine tendencija, t. y. pastebimas ryšys tarp dviejų objektų. Požiūrio i sporto psichologiją (SPA-R) metodikos skaliu patikimumas buvo tikrinamas naudojant Cronbach- $\alpha$ kriteriju.

Tyrimas. Tyrimas vyko 2006-2007 metais: 2006 m. Estijoje vykstant SELL (Suomijos, Estijos, Latvijos ir Lietuvos) studentų sporto žaidynèms, pagal SPA-R metodiką anglų, rusų ir lietuvių kalba apklausti 126 studentai sportininkai: 40 iš Lietuvos, 38 iš Latvijos, po 24 iš Estijos ir Suomijos. Apklausti 83 vyrai ir 43 moterys. Jie atstovavo šioms sporto šakoms: krepšiniui (33 asmenys), plaukimui (23), futbolui (22), lengvajai atletikai (20), tinkliniui (6), orientavimosi sportui (15), imtynėms (4) ir sunkiajai atletikai (3). Respondentų amžius $-18-29$ metai $(\overline{\mathrm{x}}=20,99)$.

\section{REZULTATAI}

Tiriant paaiškejjo, kad 56,3\% studentų sportininkų yra tolerantiški sporto psichologijos atžvilgiu, o 43,7\% mažiau arba visai netolerantiški.

Ivertinus tiriamujuc lyti ir toleranciją sporto psichologijai nustatyta, kad nèra statistiškai reikšmingo skirtumo $(\mathrm{p}=0,506)$ tarp tiriamujų lyties ir tolerancijos. Tačiau moterys yra tolerantiškesnès nei vyrai (žr. 1 lent.).

Išanalizavus studentų gyvenamosios vietos, lemiančios kultūrinius ypatumus, ir tolerancijos sporto psichologijos atžvilgiu rezultatus (žr. 2 lent.) nustatyta, kad nèra statistiškai reikšmingo skirtumo tarp šių kintamujų $(p=0,382)$. Tolerantiškiausi sporto psichologijos atžvilgiu studentai iš Suomijos $(66,7 \%)$, Estijos (62,5\%), Lietuvos (60,0\%). Tolerantiškas požiūris būdingas $42,1 \%$ Latvijoje gyvenančiu studentų, tačiau daugiau nei puse iš jų yra mažiau arba visai netolerantiški (57,9\%). Taip pat $40 \%$ Lietuvos, $37,5 \%$ Estijos, $33,3 \%$ Suomijos studentu mano, kad lankymasis pas sporto psichologą kenkia sportininko reputacijai, ir jie nenoretuc, kad kas nors apie tai sužinotu.

Statistiškai reikšmingo skirtumo tarp respondentu sporto šakos ir tolerancijos sporto psichologijos atžvilgiu nenustatyta $(\mathrm{p}=0,898)$, bet reikètu atkreipti skaitytojo dèmesi $\mathfrak{i}$ tai, kad akivaizdžiai tolerantiškesni yra individualių šakų ir jų rungčiu

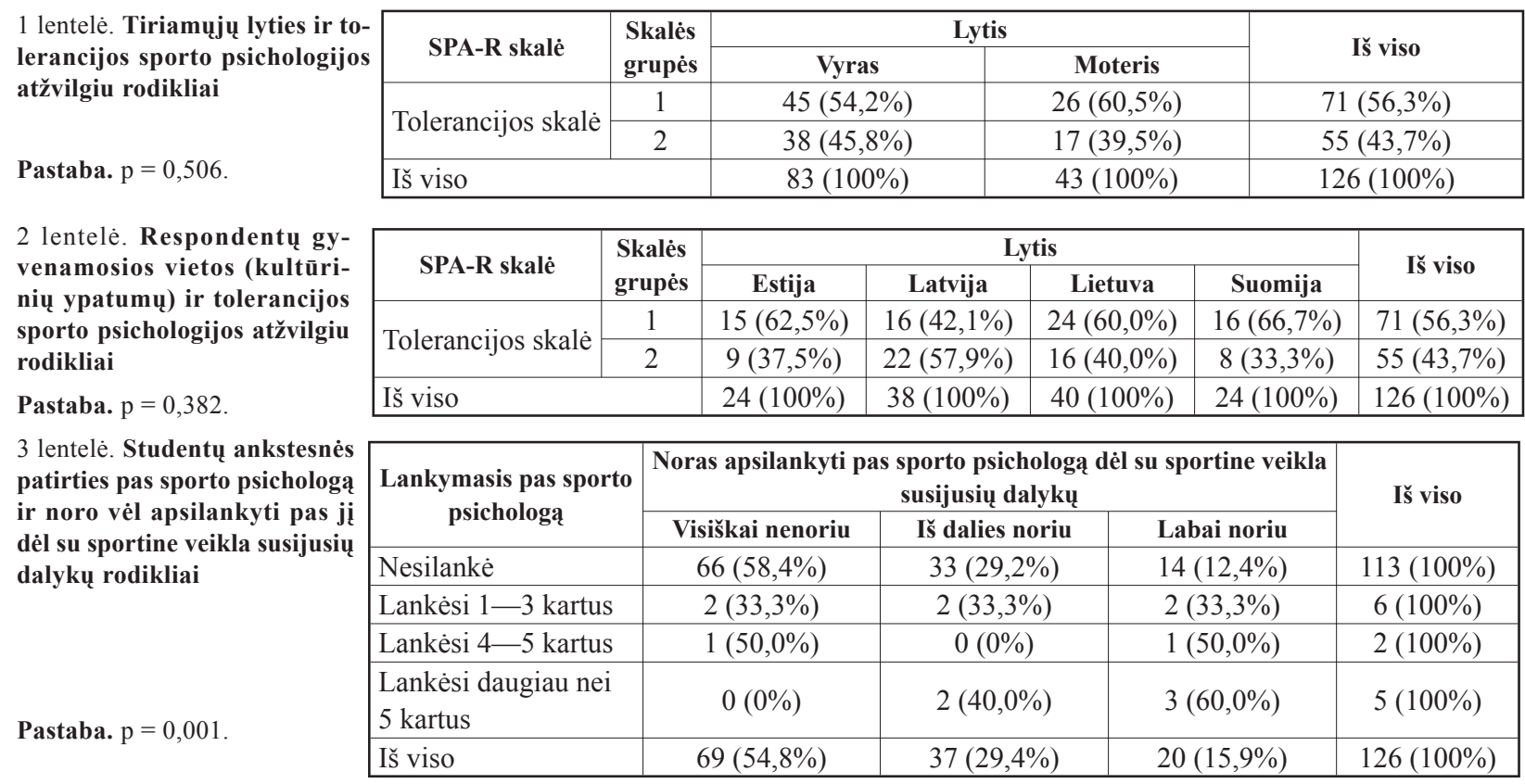




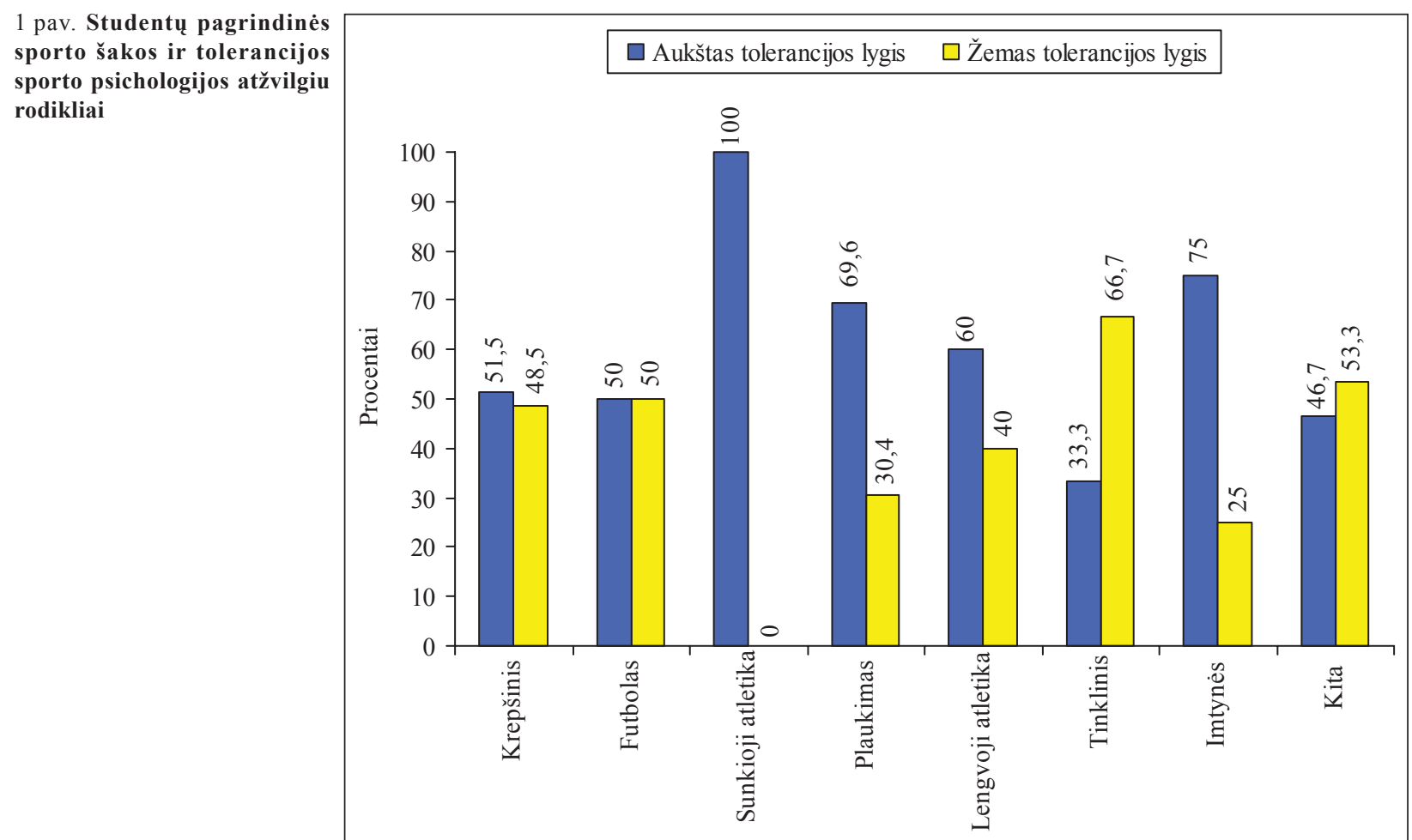

2 pav. Studentų pagrindinès domèjimosi srities ir pasitikẻjimo sporto psichologu rodikliai

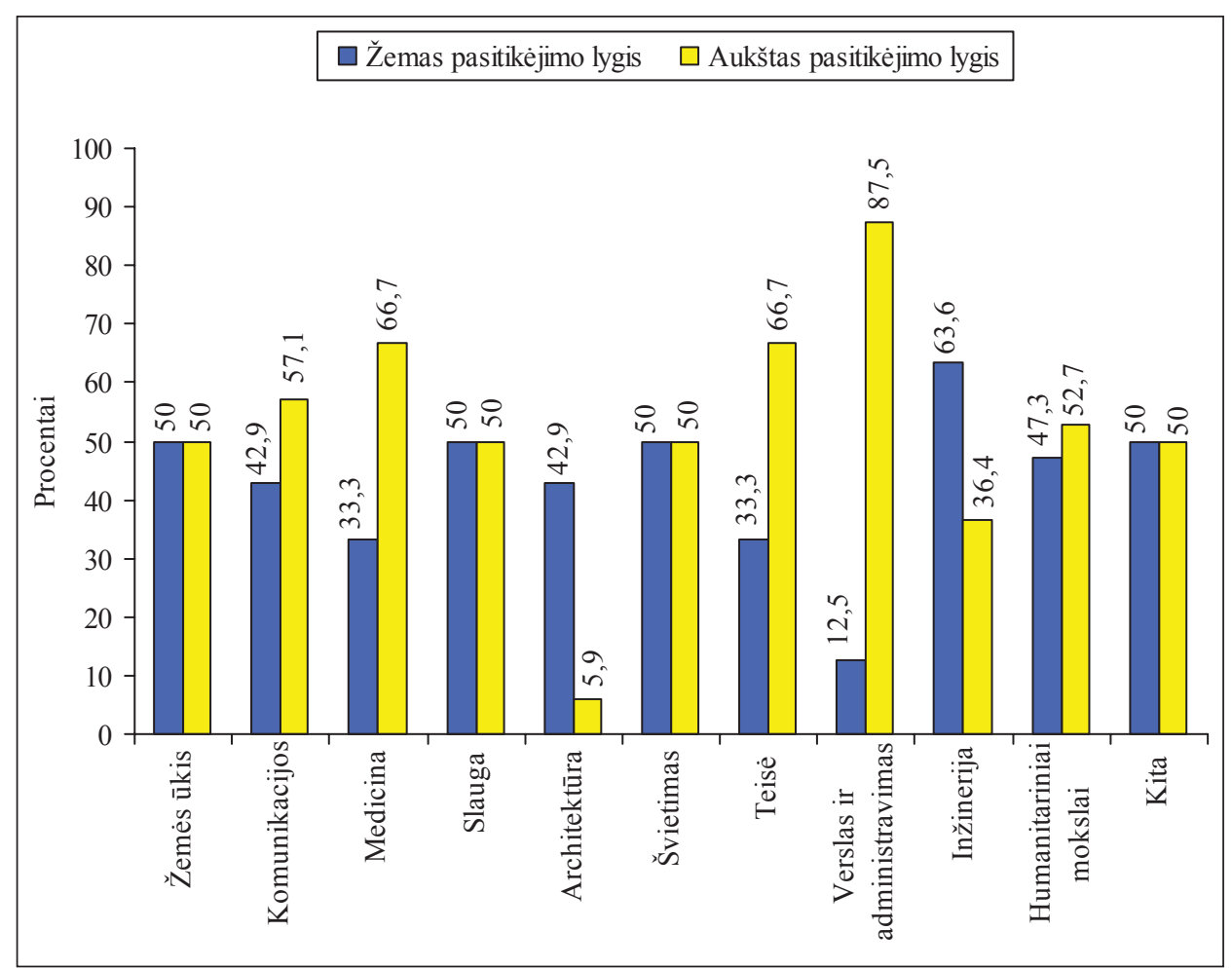

atstovai nei sportinių žaidimų šakų apklaustieji (žr. 1 pav.).

Tiriant pabandyta nustatyti būsimos profesijos ir požiūrio į sporto psichologus sąsajas. Pasirodo, nėra statistiškai reikšmingo skirtumo tarp šiu kintamuju $(p=0,440)$. Daugiausia iš apklaustu SELL žaidynių dalyvių studijuoja humanitarinius mokslus $(43,7 \%)$ ir inžineriją $(17,5 \%) .2$ paveiksle matyti, kad aukščiausiu pasitikejimo sporto psichologu lygiu pasižymi verslą ir administravimą studijuojantys respondentai $(87,5 \%)$, taip pat - teisę $(66,7 \%)$ ir mediciną $(66,7 \%)$. Aukštas pasitikejimo lygis sporto psichologu būdingas $57,1 \%$ respondentų, studijuojančių komunikacijas ir $52,7 \%$ besidominčiu humanitariniais mokslais. Apklausoje dalyvavusiems studentams, besidomintiems architektūra $(42,9 \%)$ ir inžinerija $(63,6 \%)$, būdingas žemas pasitikejjimo sporto 
psichologu lygis: ju manymu, sporto psichologo pagalba neduoda naudos.

Nustatyta, kad 54\% respondentu pasitiki sporto psichologu, t. y. apklaustieji mano, kad šis gali padèti siekti geresnių rezultatų, padèti išspręsti kylančias problemas, o $46 \%$ apklaustujų mažiau pasitiki arba visai netiki sporto psichologais.

Lyties ir pasitikejimo psichologu sąsajos statistiškai reikšmingos $(p=0,029)$ : sporto psichologu labiau pasitiki moterys $(67,4 \%)$ negu vyrai $(47,0 \%) .53,0 \%$ vyru netiki, kad sporto psichologo konsultacijos yra veiksmingos (moterų tik 32,6\%). Labiausiai sporto psichologu pasitiki Estijos respondentai $(75,0 \%)$, mažiausiai - Suomijos (tik $33,3 \%)(\mathrm{p}=0,010)$. Lietuvaičiu pasitikejjimas siekia $55,0 \%$.

Tyrimas parode, kad respondentu asmeninis atvirumas glaudžiausiai susijęs su jų išsilavinimu: atviriausi studijuojantys ar jau turintys bakalauro $(63,8 \%)$ ir magistro $(60 \%)$ laipsni, uždariausi vidurinio išsilavinimo asmenys $(63,9 \%)$ ir baige koledžą $(57,1 \%)(p=0,012)$.

Pastebèta statistinè tendencija $(\mathrm{p}=0,053)$ sąsaju tarp būsimos profesijos ir asmeninio atvirumo: atviriausios asmenybès - būsimi medikai $(77,8 \%)$ ir komunikaciju specialistai $(57,1 \%)$. Žemiausias atvirumo lygis užfiksuotas tarp švietimo $(83,3 \%)$, architektūros $(57,1 \%)$, inžinerijos $(54,5 \%)$ ir humanitarinius mokslus $(54,5 \%)$ studijuojančių apklaustujų.

Moterys kiek atviresnès $(51,2 \%)$ už vyrus $(47,0 \%)$, bet $p=0,660$. Aukščiausią asmenini atvirumą parodė Estijos (58,3\%), žemiausią Lietuvos (42,5\%) apklaustieji. Deja, kultivuojama sporto šaka ir asmeninis atvirumas susiję nepatikimai $(p=0,817)$. Nustebino tinklininku $(66,7 \%)$ ir futbolininku $(72,7 \%)$ uždarumas.

Atkreiptinas dèmesys, kad iš 61 respondento, pasižyminčio aukštu asmeniniu atvirumu, net 56 , t. y. 91,8\%, né karto nesilanké pas sporto psichologą, o iš 65 „uždaruju““ aštuoni ten apsilankè ir ne po vieną karta.

Kultūrinių ypatybių požiūriu užfiksuota sąsajų tendencija su pagrindine profesija $(p=0,080)$ ir atstovaujama sporto šaka $(p=0,084)$. Kultūrinès ypatybès kiek smarkiau veikia moteris $(58,1 \%)$ nei vyrus $(51,8 \%)$, bet $p=0,503$. Didžiausią kultūrini poveiki jaučia Suomijos respondentai $(70,8 \%)$, mažiausią - Lietuvos (45,0\%).

Paaiškèjo, kad visų 4 šalių (SELL) mūsų respondentai vyrai visai nenoretu kreiptis i sporto psichologą dèl su sportu susijusių $(67,5 \%)$ ar asmeninių $(63,9 \%)$ dalykų, o apklaustos moterys tokias nuostatas pareiške atitinkamai tik 30,2 ir $25,6 \%(\mathrm{p}=0,0001)$.

Prasčiausiai sporto psichologus vertina Suomijos apklaustieji: sporto klausimais nenorinčiu kreiptis yra 58,3\%, asmeniniais dar daugiau $66,7 \%$. Asmeniniais klausimais sukalbamiausi Estijos apklaustieji - tik 37,5\% nesikreiptu $i$ psichologa.

Nustatytos statistiškai reikšmingos $(\mathrm{p}=0,001)$ sąsajos tarp apklaustujų ankstesnès patirties pas sporto psichologą ir noro vèl apsilankyti pas ji dèl su sportine veikla susijusių dalykų (žr. 3 lent.).

Analogiški rezultatai gauti tiriant sportininku norą vèl apsilankyti pas psichologą asmeniniais klausimais.

\section{REZULTATU APTARIMAS}

Analizuodami specialiają literatūrą ir atlikdami tyrimą aptikome prieštaravimų tarp sportinio rengimo, sportininku psichoreguliacijos teorijos išplètojimo ir nūdienos sporto praktinių poreikių. Viena iš pagrindinių tos situacijos priežasčiu yra ta, kad treneriai ir patys sportininkai nepakankamai, neadekvačiai vertina psichologini rengimąsi, psichoreguliaciją sportineje veikloje.

Tyrimas parodè, kad sporto psichologija, sporto psichologo darbas bent jau tarp dalies keturiu Baltijos šaliu jaunimo yra žinojimo, deklaravimo lygio: iš 126 apklaustujų tik 13 yra susidūrę su sporto psichologu, o beveik 55\% respondentų visai nenori susitikti su psichologu.

V. N. Smolenceva (Смоленцева, 2007) tyré ivvairaus meistriškumo sportininkų (900 žmonių) požiūrị i psichologinį rengimą(-si). Nustatyta, kad didžioji dalis apklaustų (ypač aukšto meistriškumo) sportininkų suvokia psichologijos reikšmę siekiant puikių rezultatų, bet mano, kad juos rengti privalo sporto psichologas ir treneris. 51,3\% jaunu sportininkų teigia, kad psichologinis rengimasis reikalingas tik sportuojant aukščiausiu lygiu, o 57\% aukštos kvalifikacijos sportininkų nuomone, psichologinis rengimasis, būsenų psichoreguliacijos mokymasis privalo vykti jau sportinès specializacijos stadijoje, nes vèliau tai daryti reikia daug pastangų ir mažai paveiku. Mes su tuo visiškai sutinkame.

Atliktas tyrimas parodè, kad tolerantiškų sportininkų yra daugiau (54,3\%). Moterys tolerantiškesnès $(60,5 \%)$ už vyrus $(54,2 \%)$. Darome prielaida, kad tai - dèl neinformuotumo, nors T. R. Leffingwell ir kt. (2001) rašo, kad netolerancija sporto psichologijai gali rodyti, kad sportininkas neverti- 
na, net menkina sporto psichologo pagalbą. Vyru netolerancija paaiškinama jų savimone, ambicijomis, būgštavimu dèl savo reputacijos, uždarumu: pirmiau pats pabandys susidoroti su sunkumais, problemomis. Jei kreipsis i psichologą, ir apie tai sužinos draugai, treneris, kiti reikšmingi sportininkui asmenys, jis praras reputaciją. M. E. Johson (1988) taip pat nustatè, kad moterys labiau linkusios naudotis sporto psichologo pagalba nei vyrai. Šiuos duomenis patvirtina S. Martin ir kt. (2001) atlikti tyrimai.

Tyrimo metu nustatytos studentu sportininku pasitikejjimo sporto psichologu rezultatų sąsajos su jų lytimi, išsilavinimu ir tautiškumu. Didesnè dalis (54\%) respondentu pasitiki sporto psichologu. Moterys labiau tiki sporto psichologo konsultaciju veiksmingumu nei vyrai. Tautiškumo aspektu Suomijos sportuojantys studentai tolerantiškiausi sporto psichologijos atžvilgiu $(66,7 \%)$, bet jie labiausiai nepasitiki sporto psichologo konsultaciju produktyvumu: dauguma iš jų mano, kad sporto psichologas nepadès jiems pasiekti gerų rezultatú. Suomius labiau nei estus, latvius ir lietuvius veikia kultūriniai ypatumai. Tai gali būti susiję su suomiu respondentų nepasitikejjimu sporto psichologo darbo veiksmingumu. Prieinamoje literatūroje nepavyko rasti kitų mokslininkų tyrimų apie Baltijos šalių sportininkų požiūrị i s sporto psichologų darbą.

Tyrimo duomenimis, labiausiai sporto psichologu pasitiki jaunesni studentai, t. y. asmenys su viduriniu, koledžo ar bakalauro išsilavinimu. Mažiau pasitiki arba visai nepasitiki magistrantai ir magistrai. A. Anderson ir kt. (2004) padarè tokią pat išvadą: jaunesnių sportininkų ir turinčių kiek aukštesni išsilavinimą pasitikejjimas sporto psichologijos veiksmingumu nesiskiria. Tačiau šie autoriai nurodè, kad žemesnio išsilavinimo sportininkai labiau priešinasi sporto psichologo pagalbai ir netiki jo veiksmingumu.

Skirtingai nei mes, S. Martin (2005) suformulavo išvadą, kad kontaktinių šakų sportininkai (pvz., imtynių, futbolo, krepšinio) neigiamiau vertina sporto psichologo konsultacijų reikšminguma ir veiksmingumą negu nekontaktiniu (pvz., plaukimo, teniso, lengvosios atletikos ir pan.). Atlikdami tyrimą didesnio skirtumo nepastebejome.

Statistiškai reikšmingo skirtumo tarp respondentų iš įvairių šalių ir kultūrinių ypatumų nenustatyta, bet duomenys rodo, kad kultūriniai ypatumai mažiausiai veikia Lietuvos studentus, labiausiai - Suomijos ir Estijos.

Tiriant paaiškejo, kad respondentu asmenini atvirumą lemia jų išsilavinimas ir būsimoji profe- sija, o lytis, tautiškumas, sporto šaka ar lankymasis pas sporto psichologą veikia mažiau. Atvirumas būdingas $48,4 \%$ respondentų, o jų uždarumas didesnis - 51,6\%. Mūsų duomenys sutampa su B. Donohue ir kt. autoriu (2004) gautaisiais. Šie mokslininkai nustate, kad tie sportininkai, kurie nelinkę viešai, atvirai skelbti asmeninę informaciją, susiduria su vidiniu barjeru, kai reikalinga sporto psichologo pagalba. Sportininku netikejimas, skeptiškumas sporto psichologijos atžvilgiu dažniausiai ir yra pagrindinè priežastis, dèl kurios jie vengia naudotis sporto psichologo patarimais (Bull, 1991). Didžiausias asmeninis atvirumas nustatytas tarp bakalaurų ir magistrantų, o vidurinio ir koledžo išsilavinimo sportininkai yra uždaresni.

Tyrimo duomenimis, būsimos profesijos interesai taip pat turi itakos asmeniniam atvirumui: atviriausi būsimi medikai $(77,8 \%)$ ir būsimi komunikaciju specialistai $(57,1 \%)$. Paaiškèjo, kad būsimoji profesija ir noras apsilankyti pas sporto psichologą yra glaudžiai susiję $(p=0,019)$ : labiausiai norejo apsilankyti pas specialistą būsimi medikai, švietimo darbuotojai, teisininkai ir verslininkai, administratoriai, visai nenorèjo — būsimi architektai, inžinieriai, humanitarai.

Ankstesnè patirtis lemia sportininkų norą vèl kreiptis i sporto psichologą. Analogiškus duomenis pateikè D. L. Vogel, S. R. Wester (2003) ir S. Martin (2005), kurie rašo, kad apsilankymas ir teigiama patirtis pas sporto psichologa yra pagrindas ir ateityje naudotis sporto psichologo pagalba. Atlikto tyrimo duomenimis, daugiau nei 5 kartus apsilankę pas sporto psichologą respondentai vèl apsilankyti pas ji norejo labiausiai.

\section{IŠVADOS}

1. Baltijos šalių (SELL) studentai sportininkai teoriškai yra tolerantiški sporto psichologijos ir sporto psichologo darbo klausimais, o praktiškai jie netiki konsultacijos paveikumu ir tikriausiai dèl to beveik $90 \%$ apklaustujų nè karto nesilanké pas sporto psichologą. Esant galimybei, labai norètu apsilankyti pas sporto psichologą $15,9 \%$ respondentu.

2. Tolerancijos sporto psichologijai požiūriu statistiškai reikšmingo skirtumo tarp tiriamų moterų ir vyrų nustatyti nepavyko $(\mathrm{p}=0,506)$, nors moterys tolerantiškesnès $(60,5 \%)$ už vyrus $(54,2 \%)$; individualiujų šaku sportininkai tolerantiškesni sporto psichologijai už sportinių žaidimų šakų apklaustuosius. Paaiškejjo, kad tolerantiškiausi 
sporto psichologijai yra suomiu (66,7\%), mažiausiai tolerantiški latvių $(42,1 \%)$ respondentai, nors $\mathrm{p}=0,382$. Tyrimas parode, $\mathrm{kad}$ būsimoji specialybè ir noras apsilankyti pas psichologa yra glaudžiai susiję $(p=0,019)$ : labiausiai to nori būsimi medikai, švietimo darbuotojai, teisininkai, verslininkai ir administratoriai, mažiausiai - architektai, inžinieriai ir humanitarai.

\title{
LITERATŪRA
}

Anderson, A. G., Hodge, K. P., Martin, S. B. (2004). New Zealand athletes' attitudes towards seeking sport psychology consultation. New Zealand Journal of Psychology, II, $121-142$.

Bull, S. J. (1991). Personal and situational influences on adherence to metal skills training. The Sport Psychologist, $13,121-132$.

Donohue, B., Dickens, Y., Lancer, K. et al. (2004). Improving athletes' perspectives of sport psychology consultation. Behavior Modification, 28 (2), 182-193.

Johnson, M. E. (1988). Influences of gender and sex role orientation on help-seeking attitudes. Journal of Psychology, 122, 237-241.

Leffingwell, T. R., Rider, S. P., Williams, J. M. (2001). Application of the transtheoretical model to psychological skills training. The Sport Psychologist, 15, 168-187.

Martin, S. B. (2005). High school and college athletes' attitudes toward sport psychology consulting. Journal of Applied Sport Psychology, 17, 127-139.

Martin, S. B., Kellmann, M., Lavalle, D., Page, S. J. (2004). Attitudes toward sport psychology consulting of adult athletes from the United States, United Kingdom and Germany. International Journal of Sport \& Exercise Psychology, 2, 146-160.
Martin, S. B., Kellmann, M., Lavalle, D., Page, S. J. (2002). Development and psychometric evaluation of the Sport Psychology Attitudes-Revised form: A multiple group investigation. The Sport Psychologist, 16, 272-290.

Martin, S. B., Kellmann, M., Lavallee, D., Page, S. J. (2001). The Sport Psychology Attitudes-Revised from Manual. Unpublished test manual. Denton, TX: University of North Texas, Department of Kinesiology, Health Promotion and Recreation.

Vogel, D. L., Wester, S. R. (2003). To seek help or not to seek help: The risk of self-disclosure. Journal of Counceling Psychology, 50, 351-361.

Смоленцева, В. Н. (2007). Психорегуляция в практике современного спорта: материаль международной научной конференции психологов физической культурь и спорта «Рудиковские чтения» (11-14 июня 2007 г.). Москва. С. 127.

Сопов, В. Ф. (2007). Система психологического обеспечения отбора и многолетней подготовки юных спортсменов в УОР: материаль международной конференции психологов физической культуры и спорта «Рудиковские чтения» (11-14 июня 2007 г.). Москва. C. 128.

\section{OPINION OF PARTICIPANTS OF THE SELL GAMES ON SPORT PSYCHOLOGY AND THE ACTIVITIES OF SPORT PSYCHOLOGIST}

\author{
Juozas Kasiulis \\ Lithuanian Academy of Physical Education, Kaunas, Lithuania
}

\begin{abstract}
According to sport specialists, it is psychological preparedness of the athletes that predetermines success in sports competition, and what is the opinion held by the athletes themselves on this point?

The aim of the research was to analyze the opinion of athletes-students on sport psychology and the activities of the sport psychologist. The research implied the solution of the following tasks: 1) to study the opinion of athletes-students on sport psychology and the activities of the sport psychologist, and 2) to establish the links between the gender, kind of sport chosen, environment and profession of the respondents and their attitude to sport psychology and the activities of the sport psychologist.

The object of the research was sport psychology and the activities of the sport psychologist from the standpoint of athletes-students.

The methods used in the research were as follows: the analysis of special literature on the subject; methods proposed by S. B. Martin et al. (2002) - Attitude (in a more specific form) to sport psychology (SPA-R) and methods of mathematical statistics.

SPA-R is made up of 2 parts: part 1 contains information about the respondent, and part 2 is given to establish the respondent's tolerance with respect to sport psychology, his / her trust in the sport psychologist as well as openness and cultural peculiarities of the respondent.
\end{abstract}


For statistical data processing the Microsoft Office Excel 2003 programme and the SPSS 13.0 version of the programme package were used. For data analysis Pearson's correlation coefficient was applied and the scale reliability of the methods of attitude to sport psychology (SPA-R) was verified by means of Cronbach's alpha.

During the SELL (Suomi, Eesti, Latvia, Lietuva) Students' Sport Games held in Estonia in the year 2006 using the SPA-R methods 126 athletes-students ( 83 men and 43 women among them), representatives of various kinds of sport, and from different universities ( 40 from Lithuania, 38 from Latvia, 24 from Estonia and 24 from Finland) were inquired by means of questionnaires. Free choice of the English, the Russian or the Lithuanian languages was given to the students inquired.

The research showed that $56.3 \%$ of the athletes-students inquired were tolerant with respect to sport psychology, whereas the remaining $43.7 \%$ of the respondents were less tolerant or showed no tolerance whatever. The percentage of tolerant women $(60.5 \%)$ was slightly higher compared to that of men $(54.2 \%)$ but this difference could not be considered statistically reliable $(\mathrm{p}=0.506)$. Living surroundings predetermine cultural differences. The research showed respondents from Finland to be the most tolerant to sport psychology, whereas representatives of Latvia turned out to be the least tolerant ones, i.e. $66.7 \%$ and $42.1 \%$ accordingly. The opinion that visiting sport psychologist was detrimental to their reputation and they would not be willing anybody to learn that they had consulted a specialist of this field was shared by $57.9 \%$ respondents from Latvia, $40.0 \%$ - from Lithuania, 37.5\% - from Estonia and 33.3\% respondents from Finland respectively.

The research revealed statistically significant $(\mathrm{p}=0.029)$ links between the gender of the respondents and their trust in sport psychologist. Thus, women showed greater trust in sport psychologist compared to men $(67.4 \%$ and $47.0 \%$ accordingly). Respondents from Estonia tended to trust sport psychologist the most $(75.0 \%)$, whereas athletes from Finland - the least of all (33.3\%). This figure among representatives of Lithuania amounted to $55.0 \%(\mathrm{p}=0.010)$.

The research showed personal openness of the respondents to be most closely associated with their education. Thus, students and those with Bachelor's degree or Master's degree turned out to be the most open ones (63.8\% and $60.0 \%$ respectively), whereas persons with secondary education and college graduates proved to be the least open ones $(63.9 \%$ and $57.1 \%$ accordingly) $(\mathrm{p}=0.012)$.

We have noticed a statistically significant tendency $(\mathrm{p}=0.053)$ of links between the future profession of the respondents and the degree of their openness: would-be specialists of medicine and communications showed the highest degree of openness ( $77.8 \%$ and $57.1 \%$ accordingly), whereas would-be specialists of education $(83.3 \%)$, architecture $(57.1 \%)$, engineering $(54.5 \%)$ and humanities $(54.5 \%)$ were the least open ones.

The results of the research done enabled us to make the following conclusions: athletes-students from the Baltic countries (SELL) were tolerant with respect to sport psychology and the activities of the sport psychologist. In practice, however, they saw no point in consulting sport psychologist since $90 \%$ of those questioned never consulted sport psychologist and merely $15.9 \%$ respondents would like to consult one.

No statistically significant difference $(\mathrm{p}=0.506)$ concerning tolerance to sport psychology between women and men inquired were found though women proved to be more tolerant $(60.5 \%)$, compared to men (54.2\%). Athletes going in for individual kinds of sport turned out to be more tolerant with respect to sport psychology than those engaged in sports games.

The research showed close links between the future profession and willingness of athletes-students to consult sport pshychologist ( $\mathrm{p}=0.019$ ). The most willing to get sport psychologist's consultation were would-be specialists of medicine, education, law and business administration, whereas would-be architects, engineers and humanitarians were the least willing ones. The fact that merely 13 persons out of 126 persons inquired consulted sport psychologist gives food for thought.

Keywords: sport psychology, activities of sport psychologist, tolerance to sport psychology, trust, openness, cultural peculiarities.

Gauta 2007 m. lapkričio 13 d.

Received on November 13, 2007

Priimta $2008 \mathrm{~m}$. vasario $20 \mathrm{~d}$.

Accepted on February 20, 2008

Juozas Kasiulis

Lietuvos kūno kultūros akademija

(Lithuanian Academy of Physical Education)

Sporto g. 6, LT-44221 Kaunas

Lietuva (Lithuania)

Tel +370 37209050 